REGE

29,2

Received 12 March 2021

Revised 20 July 2021

Accepted 19September 2021

\title{
Manezinho who makes good food: Restaurante do Costinha
}

\author{
Pedro José Raymundo \\ IFSC, Florianópolis, Brazil and UNIVALI, Biguaçu, Brazil, and \\ Diego Hernando Florez Ayala, Ullian Fadu Naatz and Anete Alberton \\ UNIVALI, Biguaçu, Brazil
}

\begin{abstract}
Purpose - The aim is to enable debates about the need for changes in the restaurant's management posture regarding food waste.

Design/methodology/approach - This study is a teaching case about a restaurant and was prepared based on information collected from the authors' experiences in teaching, consulting, and academic research. The plot, company name, and characters are fictitious.

Findings - The results are related to the classroom application to promote discussion and knowledge of topics such as finance, costs, sustainability, food waste, and the Demonstration of Results for the Exercise.

Research limitations/implications - The main limitation is that it is a fictitious study, but it allows applied research based on the authors' scientific knowledge and professional practice.

Practical implications - The theme contributes to anchoring decision-making by managers in the face of day-to-day business challenges. Furthermore, in a contemporary perspective, it involves a small establishment concerning the possibilities of contributing to the Sustainable Development Goals (SDGs). Furthermore, due to the richness of details, the case constitutes an intriguing teaching tool to be applied in the classroom.

Social implications - It impacts social actions, according to the examples found in the narrative used in the teaching case.

Originality/value - Its originality is related to its interdisciplinarity and how it involves the themes of finance and sustainability applied in business practice.
\end{abstract}

Keywords Finance, Business costs, Sustainability, Income statement, Waste management

Paper type Case study

\section{Introduction}

Saturday afternoon, a warm sunny beach, in the summer of 2019, in the south of Ilha de Santa Catarina (Florianópolis), the restaurant was packed, and many people were waiting to be served. Mariana, wife, and partner of Mr. Aquiles Costa, better known as Costinha, went to help clear one of the tables where they had served lunch to a family of four. The restaurant, specialized in seafood, with five years of existence and very well attended, had the special care of Mariana. She took care of marketing and cash flow, and had seen the financial results going from strength to strength.

But at that moment she was shocked. With a pang in her heart, she dumped nearly half of the food from that table into the trash. There were leftovers from the shrimp side dishes (rice, salads, mush (pirão), beans, bean broth, farofa and potatoes). When the busy period in the restaurant had died down and the last customers had left, Mariana vented her frustration:

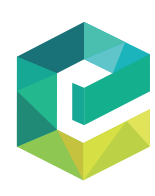

Revista de Gestão Vol. 29 No. 2,2022 pp. $158-174$

Emerald Publishing Limited

e-ISSN: $2177-8736$

p-ISSN: $1809-2276$

DOI 10.1108/REGE-03-2021-0040
(C) Pedro José Raymundo, Diego Hernando Florez Ayala, Ullian Fadu Naatz and Anete Alberton. Published in Revista de Gestão. Published by Emerald Publishing Limited. This article is published under the Creative Commons Attribution (CC BY 4.0) licence. Anyone may reproduce, distribute, translate and create derivative works of this article (for both commercial and non-commercial purposes), subject to full attribution to the original publication and authors. The full terms of this licence may be seen at $\mathrm{http} / / /$ creativecommons.org/licences/by/4.0/legalcode

Agradecimento aos Financiadores: Programa Uniedu/Fumdes Pós-Graduação. 
- Costinha! From just one table alone that I helped to clear, more than a kilo of food was thrown away. How could this happen?

Costinha was the partner in charge of the kitchen's production and was taken by surprise by Mariana's questioning. Even without quite knowing how to answer, he argued:

- Don't worry so much, Mariana! I don't think it's always like that. Anyway, look on the bright side, even if there is a lot of food left on the tables, the customer has paid for it all. In the case of this customer, for example, he must have paid at least $\mathrm{R} \$ 300$ in all.

- Yes, Costinha, we are growing a lot and seeing excellent financial results, but we can't ignore this serious problem of food waste, Mariana replied.

At Mariana's insistence, they talked to all the employees about the issue. They found that it was very common for customers to leave a lot of food on their plates, especially from the large portions of accompaniments.

Given this situation, Costinha thought better of the matter and added:

- So, Mariana! I don't know, but for me the biggest problem is being able to reduce waste without losing customers, who are used to being offered large quantities of food.

Mariana's agony when witnessing the amount of wasted food, on just one table, is understandable. She recently started new sustainable practices in the restaurant, thinking about the environmental impacts on its surroundings.

\section{Background}

To understand how the restaurant was positioned in the Florianópolis market, it is necessary to go back to the past. It all started with a dream, which came to fruition through hard work. The dedication of the two partners, who had a lot of life experience, was an integral part of this success. Costinha, with his special technical and professional knowledge in gastronomy and Mariana, acting as administrator, with specialized studies in planning and marketing. They were celebrating their second wedding anniversary when they began renovating a rented property, which had a spacious building and ample land.

With a very significant investment, they spent all their savings and even took out family loans, which were paid off as soon as the restaurant started to show positive returns. In the beginning, there were many setbacks, such as the lack of resources for the initial investment, which totaled $\mathrm{R} \$ 173,270$, which should fully depreciate after five years.

Another difficulty was the small number of employees, just one chef, an assistant and two waiters. Even so, they managed to kick-start the realization of their dream, with Restaurante do Costinha, inaugurated in March 2015. The name of the restaurant is the nickname affectionately given to Costinha by his uncle João, with whom he worked for many years and had a father-son relationship.

Mariana, with her experience in administration and marketing, and a focus on customer satisfaction, was always attentive. In relation to market competition, she asked Costinha:

- Costinha! The competition in the area of seafood is very high. You know that, right!?

- Of course, Mariana! That's why we're going to have to do a good job, replied Costinha.

- That's right! We also must follow our planning very carefully and differentiate ourselves, with excellent service, argued Mariana.

They invested in marketing campaigns and paid for publicity ads, which were viewed on social media. In addition, thinking of ways to win customers, Mariana planned low-cost dishes and some free courtesy items for new visitors. To ensure the customers would be 
REGE

29,2 delighted, Costinha looked closely at each service, instructing the employees to always wait upon the tables with a smile and provide prompt service.

Besides being the owner, Costinha was also the manager and a waiter. Through quality service, customer recommendations, use of social media marketing and apps, the restaurant achieved true financial success after five years.

\section{0}

\section{The company}

Restaurante do Costinha was set up by the two partners, Costinha and Mariana, who have had entrepreneurial interests from an early age. Costinha is 45 years old and was born in Florianópolis. His entrepreneurial spirit was inspired by his uncle, at restaurant he worked since he was young. Hence, Costinha has always worked in the area of gastronomy. He would peel potatoes, wash dishes, take out the garbage and charge the customers, but what he enjoyed most was cooking.

He took a technical course in gastronomy and went on to fulfill his dream of opening his own restaurant. He shared all this with Mariana, to whom he has been married for seven years, building a story not only of his personal life, but also of professional achievement.

With experience, Mariana kept the cash flow in order and helped with various other tasks. A big contributing factor to the success of the restaurant, in addition to Costinha's experience, the location of the restaurant, and the customer's preference for seafood, was the marketing plan drawn up by Mariana. She created budgets that included all the forecast costs, investments and returns.

In addition to this financial perspective, Mariana's entrepreneurial spirit led her to propose ideas on issues such as environmental impacts on the community and sustainable practices with clients. These included prioritizing local suppliers who work with organic products through family farming, contributing to the preservation of natural resources. Through these initiatives, she was able to steer the restaurant towards a healthy eating style, with less impacts on the environment.

Mariana found that in Florianópolis, approximately 4000 search per month are conducted on health eating. This information helped Mariana make Costinha aware of the importance of a menu aimed at this audience. Sustainability was always a key part of Mariana's plans, and for this, she needed her partner's support.

The restaurant is typical of the region. It is next to the sea, in the south of Ilha de Santa Catarina, in the municipality of Florianópolis. Its characteristics are specialization in fish and seafood; five years in existence; eight employees (six working in the kitchen and six in the restaurant), annual costs of 470.7 thousand Brazilian reals, including all labor charges, in addition to the salaries of Mariana and Costinha. Mariana seeks to hire employees from the local region, thinking about the professional insertion of these people and also to facilitate the restaurant's engagement in local social activities such as oyster parties, fetes and activities on commemorative dates, whether religious or secular.

With a turnover of up to 1.5 times in its 100 seats, the restaurant can serve up to 150 customers per day. It is open every day of the week, except Mondays, and provides à la carte service, with a menu that gives the names of the dishes, accompaniments and portions, and their respective selling prices. There are more than 80 options on the menu, including starters, salads and mains.

Each year, it serves an average of 28 thousand customers, and in the summer season alone, from December to March, this number is close to 16 thousand. Between April and November, the less busy months, Mariana adjusts the employees' schedules accordingly. This flexibility is subject to training courses that compensate for the reduction in working hours.

The décor is another feature that delights customers, making them feel welcome and at ease. Mariana and Costinha planned a family-oriented environment, with various plants and 
a mini aquarium to delight children and adults alike. The décor is inspired around a theme of fishing and the sea, while the furniture has a beachy feel. Various pictures decorate the walls, showing local scenery and dialect.

The lighting is warm, with cozy wooden light fittings. At night, the restaurant reserves more intimate tables for romantic couples, close to plants. Special areas are prepared for celebrations, such as Valentine's Day and birthdays.

Concerning the ambience and décor of restaurant, Mariana sighed happily, at the end of a busy night:

- Costinha, this music played in our restaurant is perfect! Bossa nova, samba and reggae accompanying the customer's conversations, together with their families, enjoying all this comfort and the tasty dishes, it a dream come true!

The two-story restaurant has a beautiful view of the sea. Guests can admire the island's natural beauty in an easily accessible region, with free parking. In the background, there is a pretty garden with a play area for children.

However, the restaurant has to pay 180 thousand reals a year in rent. The lease is on a fiveyear contract, and the rent is adjusted for annual inflation: IPCA. Other expenses and fixed expenses amount to 350 thousand reals per year, which includes costs like water, energy, internet, insurance, fees, equipment maintenance and replacement of utensils such as dishes and cutlery.

The restaurant fits into the taxation model of the Simples Nacional law, a tax collection system for micro and small businesses that simplifies the payment of taxes. Restaurante do Costinha is classified at a rate of $10.14 \%$ on sales, in accordance with this law (Brasil, 2006).

The clientele consists largely of families of four to eight people, who live in the city of Florianópolis. However, on weekends, customers from the interior of Santa Catarina, Rio Grande do Sul and Paraná also visit. The restaurant has conquered this special group: large families, which generates more than half of its income. Although it is not a traditional restaurant, it managed to position itself by identifying the advantages of serving this audience.

The consumption behavior of its customers includes main dishes, side dishes, drinks and desserts. Even with the side dishes in abundance, it seems that people cannot hold back when ordering food. They usually ask for far more than they actually consume. Each customer spends an average of $R \$ 65.00$ on food (Table 1) and $R \$ 10.00$ on beverages, making up the so-called average ticket of $\mathrm{R} \$ 75.00$, which is the average total expenditure per person, including food and beverages. Desserts are provided courtesy of the house.

\section{The product}

The main product of Restaurante do Costinha is seafood. Its menu includes a wide variety of dishes, including fish, shrimp, squid, oysters, octopus and other seafood. Due to its proximity of the sea, and suppliers, it maintains excellent quality products. All the seafood is fresh and tasty, further enhancing the delicacies prepared by Costinha's own hands or under his immediate supervision. It also offers some types of meat and poultry, but its customers usually prefer the house specialties. To accompany the dishes, excellent national and imported wines are available, as well as natural juices, beers and soft drinks.

Costinha jokes happily with some of his regulars:

- We have almost anything that comes from the sea on our menu, for you to enjoy!

Mariana perceives that her constant concern with the local fauna and flora, and her efforts to strengthen the image and add value to the company, are key factors for personal and professional fulfillment. She also knows that this form of management contributes to the 


\begin{tabular}{|c|c|c|c|c|}
\hline \multirow[t]{2}{*}{$\begin{array}{l}\text { REGE } \\
29,2\end{array}$} & $\begin{array}{l}\text { Product/ingredient } \\
\text { Fish stew }\end{array}$ & $\begin{array}{l}\text { Sides } \\
\text { tables and mush (pirão) }\end{array}$ & \multicolumn{2}{|c|}{ No. of people served } \\
\hline & Ingredients & Amount. Kg & Unit & Total \\
\hline \multirow[b]{3}{*}{162} & Badejo Fillet & 0.550 & $\mathrm{R} \$ 35.00$ & $\mathrm{R} \$ 19.25$ \\
\hline & Palm oil & 0.040 & $\mathrm{R} \$ 14.00$ & $\mathrm{R} \$ 0.56$ \\
\hline & Garlic & 0.020 & $\mathrm{R} \$ 23.90$ & $\mathrm{R} \$ 0.48$ \\
\hline \multirow{17}{*}{$\begin{array}{l}\text { Table } 1 \text {. } \\
\text { Date sheet for fish stew } \\
\text { (moqueca) }\end{array}$} & Onion & 0.100 & $\mathrm{R} \$ 2.90$ & $\mathrm{R} \$ 0.29$ \\
\hline & Tomato & 0.100 & $\mathrm{R} \$ 3.80$ & $\mathrm{R} \$ 0.38$ \\
\hline & Green pepper & 0.020 & $\mathrm{R} \$ 5.80$ & $\mathrm{R} \$ 0.12$ \\
\hline & Red pepper & 0.040 & $\mathrm{R} \$ 14.00$ & $\mathrm{R} \$ 0.56$ \\
\hline & Yellow pepper & 0.040 & $\mathrm{R} \$ 14.00$ & $\mathrm{R} \$ 0.56$ \\
\hline & Coconut Milk & 0.200 & $\mathrm{R} \$ 16.50$ & $\mathrm{R} \$ 3.30$ \\
\hline & Coriander & 0.030 & $\mathrm{R} \$ 7.50$ & $\mathrm{R} \$ 0.23$ \\
\hline & Salt & 0.020 & $\mathrm{R} \$ 3.50$ & $\mathrm{R} \$ 0.07$ \\
\hline & Black pepper & 0.005 & $\mathrm{R} \$ 16.80$ & $\mathrm{R} \$ 0.08$ \\
\hline & Rice & 0.400 & $\mathrm{R} \$ 2.90$ & $\mathrm{R} \$ 1.16$ \\
\hline & Vegetables & 0.400 & $\mathrm{R} \$ 6.50$ & $\mathrm{R} \$ 2.60$ \\
\hline & Pirão & 0.400 & $\mathrm{R} \$ 9.50$ & $\mathrm{R} \$ 3.80$ \\
\hline & Total kg & 2.365 & Total COGS & $R \$ 33.43$ \\
\hline & Sale price & $R \$ 130.00$ & Profit $R \$$ & $R \$ 96.57$ \\
\hline & COGS\% & $25.72 \%$ & Profit\% & $74.28 \%$ \\
\hline & $K g$ cost & $R \$ 14.14$ & Cost per customer & $R \$ 65.00$ \\
\hline & \multicolumn{4}{|l|}{ Source(s): The authors (2021) } \\
\hline
\end{tabular}

statistical data, which indicate that the southern region is the largest consumer of organic products in Brazil.

In the way she conducts her business, Mariana considers several aspects, such as a) a specialization in seafood; b) a focus on the use of organic products in the menu; c) a preference for local suppliers; d) purchasing from small family farms and e) involvement of the restaurant in the activities and traditions of the local community. Now, she dedicates her efforts to improving the food production process, aiming at reducing waste, as well as making structural alterations to the property for the installation of rainwater and solar energy collection systems, resulting in a forecast $\mathrm{R} \$ 3000$ reduction per month, on water and energy expenses.

The restaurant's customers, interested in this type of food, are demanding and loyal. Their biggest concern is with health and well-being, a perspective that goes beyond the plentiful and tasty food. These consumers demand meals prepared using raw materials that are in line with the sustainability process. They also want quality service, to ensure a pleasant and memorable visit.

So when the customer orders a dish such as Fisch mush, which is one of the best-selling specialties, every effort is made to satisfy the customer. A beautiful and tasty cumbuca with the succulent main preparation of the fish arrives promptly at the table, as well as portions with side dishes such as rice, vegetables and mush. This option is for two people, and carries a price of $\mathrm{R} \$ 130.00$. The cost of the raw materials for the restaurant to prepare these foods is $\mathrm{R} \$ 33.43$, and the total weight of the food is $2.365 \mathrm{~kg}$.

These numbers are all included in the technical sheet, which is a fundamental tool for gastronomic production. But Restaurante do Costinha does not yet use this tool. However, concerned about waste, Mariana prepared a technical sheet (Table 1). For this, she carried out research, including searching in the materials from Costinha's technical course in gastronomy, which he had stored carefully since completing the course. 
In addition to the figures already mentioned, the technical sheet shows other information that is worth mentioning, such as the gross profit margin of $\mathrm{R} \$ 96.57$ (74.28\% on the sale price); the cost of goods sold (COGS) of $25.72 \%$ on the sale price; the average cost per kilo of inputs ( $\mathrm{R} \$ 14.14)$ and the average amount spent on food per customer $(\mathrm{R} \$ 65.00)$.

\section{Next steps}

As a dedicated professional, Costnha is very concerned with customer satisfaction and always is always on the lookout for criticism or praise. He follows posts on the social networks and is proud when comments are made in praise of his food:

- I've never eaten anything like it! Costinha's fish stew (moqueca) is like a recipe from the Gods!

Others praise the qualities of food, and the large amounts of food, served freely:

- Plenty, good and cheap food? Costinha's restaurant, where everything is good!

But there are also those who are uncomfortable with this "abundance." Costinha is not keen to show comments like this:

- Look! I go to a restaurant like this to eat a fish or shrimp with a beer, not to stuff myself with rice, potatoes, farofa...

In addition to the aspect related to customer satisfaction, the restaurant is also profitable. However, customer satisfaction and profits are not everything, especially for Mariana, who is enlightened and updated on events related to her area of expertise.

She is always attentive to information in her area, such as a report from the United Nations Food and Agriculture Organization (FAO), 2017, warning that 30\% of world food production (1.3bn tons) is lost or are wasted annually (FAO, 2017). She also knows that customers are increasingly concerned about environmental issues and are becoming more demanding when it comes to sustainable consumption.

Concerned by the situation of food waste she saw that day, when she went to help clear a table on which so much food had been left, Mariana managed to get Costinha to agree to conduct a proper survey on the amount of wasted in the restaurant. All food sent to the trash was weighed each day for a week, including table scraps and expired foods that had been prepared but not served.

Dividing the total weight of these foods destined for the trash by the number of customers that week, Mariana found that the waste of the leftovers at the tables was $200 \mathrm{~g}$ per customer. And for foods prepared but not served, the amount of waste was $50 \mathrm{~g}$ per customer, making a total of $250 \mathrm{~g}$ of food waste per customer served in the period.

Faced with this reality, Costinha reflected:

- Yeah, you're right Mariana, the waste is huge! With $250 \mathrm{~g}$ per person and 28,000 customers served, that's $7000 \mathrm{Kg}$ of waste per year. But, should we take the risk of changing the way we produce and serve the food, when everything is going so well? Would we not run the risk of ruining everything?

On the one hand, Costinha is happy with the financial results and abundance of the menu, which he considered to be one factor in the customers' satisfaction. On the other, Mariana is dissatisfied with the large volume of food waste.

Keeping all types of customers happy is a big challenge, as some like plentiful dishes while others are more concerned about waste and sustainability. Is it possible to reconcile the financial results with quality and customer satisfaction in relation to waste reduction? 
REGE

29,2

164

\section{Teaching notes}

\section{Obtaining the data}

This teaching case focusing on Restaurante do Costinha was prepared based on information collected from the authors' experiences in teaching, consulting and academic research. This type of case is known as an "armchair" case (Campos \& Almeida, 2014). The plot, company name and characters are all fictitious.

\section{Protagonists}

The protagonist Costinha has a vision focused on customer satisfaction and financial results, aspects in which his restaurant is doing very well. So for Costinha, if everything continued as it was, things would be perfect.

His wife and partner, Mariana, plays a supporting role, but at several critical moments, it is her opinions that come to the fore, and weigh strongly in the decision-making. For her, the concern with sustainability, specifically, with food waste, is an overriding factor in her decision-making regarding changes in the management of production and restaurant services.

\section{Recommended use}

This case was designed to be used mainly with lato sensu undergraduate and graduate students in the areas of business administration and other areas involving management, such as gastronomy and tourism. The most suitable subject areas for its application are financial management and managerial costs. Additionally, it can be used in disciplines involving menu management and sustainability.

The highlights of this case are (1) its field of application, especially financial management and costs, as most teaching cases are focused on the areas of strategy and marketing and less on people management, logistics and finance (Faria \& Figueiredo, 2013); (2) the lack of research on cost management, results and menu management (Linassi, Alberton, \& Marinho, 2016), highlighting the need for more research involving these themes; (3) it meets the demand for the submission, publication and use of cases for teaching in Brazil (Alberton \& Silva, 2018).

Thus, it is expected that the case will enable students to develop skills in decision-making in the areas of financial and cost calculations. The students will be able to reconcile theoretical knowledge with their professional practice, especially as it is a typical application case (Ikeda \& Campomar, 2005), one of the purposes being to clarify the importance of implementing management tools, such as the income statement of the exercise and the technical data sheet for food preparation. Students will also learn how to associate management aspects with contemporary themes of relevant social importance, such as sustainability.

\section{Teaching objectives}

This teaching case presents a dilemma in which the managers of a restaurant, Costinha and Mariana, must make a decision on whether or not to change the way they administer their production and services, especially regarding food waste.

Costinha seems satisfied with the status quo, claiming that the financial results are rewarding and that the proposed changes could cause them to lose clientele. Mariana, concerned with sustainability, cannot accept so much waste. Thus, some points for discussion and learning can be highlighted that will assist at the start of application of the case in the classroom:

(1) Identify issues involving data management and control in small companies, such as calculating the results (profit or loss) or unnecessary costs, such as waste: What is the 
level of concern in companies when it comes to issues related to waste? How can we measure this waste in order to control it?

(2) Discuss the use of management tools such as food preparation datasheets and the use of electronic spreadsheets, with questions such as: What electronic systems are used in companies of this size? If you use these systems, how do you use their functionalities for management? If not, how can we implement their use to improve the quality of the production process?

This case may also be used to develop participants' skills involving three levels of learning:

(1) Conceptual learning: students will be able to expand their conceptual knowledge of financial results, costs, control tools and sustainability.

(2) Skills development: they will be able to learn to use tools such as electronic spreadsheets for the elaboration of technical sheets and calculation of results, as well as how to quantify food waste.

(3) Attitudinal aspect: students will have learning opportunities that promote attitudes towards the use of control tools to regulate, for example, food waste and attitudes towards sustainability such as consuming food consciously; avoiding food waste in the meals and the proper disposal of waste.

\section{Suggested teaching plan}

For the teacher to conduct the case, we propose the following teaching plan, with time forecasts that may vary according to the subject to be worked on (cost area and financial management or sustainability) or the level of the course, remembering that in graduate courses, students are expected to share their professional experiences, broadening and deepening the debates.

The teacher must make the case available in advance for the students to read. It is important that students come to class having read the case and understood all the calculations. To expand the possibilities for debate, we suggest that the teacher ask students to carry out some research in advance, on the Internet, looking at some cases of sustainable restaurants. The total application time should be around 200 minutes, as shown in Table 2.

Duration $\quad \begin{aligned} & \text { Activities } \\ & 30 \mathrm{~min}\end{aligned}$
$\begin{aligned} & \text { Discussion of the case in small groups of two or three students to answer questions about the } \\ & \text { calculations, if any }\end{aligned}$
$\begin{aligned} & \text { A session with the entire class, in which voluntary or randomly picked groups can present } \\ & \text { Table 1, the technical form, and the results of the discussions on to the proposed questions }\end{aligned}$
A se-60 min $\begin{aligned} & \text { A session with the entire class, guided by the teacher, encouraging all the participants to give } \\ & \text { their opinions on the issues }\end{aligned}$
$\begin{aligned} & \text { If there are computers or similar equipment available for the students and if the teacher is } \\ & \text { interested, this period can be used to build the electronic spreadsheets to help solve problems, } \\ & \text { such as the elaboration of technical sheets and demonstration of results of the exercise. } \\ & \text { Otherwise, this time can be used to continue the debate in relation to various managerial aspects } \\ & \text { that occur in companies like the restaurant in question, such as finances, environmental issues, } \\ & \text { employee training and customer awareness in relation to consumption }\end{aligned}$
Closing the case

Source(s): The Authors (2021)

Table 2.

Application of activities 
REGE

29,2

\section{6}

Questions for analysis

Below are questions that can be used to stimulate analysis and discussion of the case:

(1) Reflect on the results of Restaurante do Costinha. For this, prepare the annual income statement (DRE), considering the information about the case. Analyze the levels of COGS, gross profit, rent, salaries and other expenses in relation to revenue. Estimate the internal rate of return and discuss the profitability of the business

(2) Redo the technical sheet (Table 1 ) with a $25 \%$ reduction in the quantities of rice, vegetables and mush.

- With the new COGS generated, also redo the DRE and analyze the results.

- Analyze the waste before and after restructuring the technical file. Check if this new waste rate might be acceptable to Mariana.

(3) Restaurante do Costinha performs several sustainable practices. Given this reality:

- Indicate the restaurant's current practices and reflect on the improvements that could be implemented.

- Analyze the social, environmental and economic impacts caused by the sustainable practices of Restaurante do Costinha, including its improvements.

(4) Associate the actions that Restaurante do Costinha already practices or that it could practice, with the SDGs (Sustainable Development Goals).

\section{Case analysis}

The theories needed to analyze and discuss the proposed questions are related to the DRE and its components, such as COGS, fixed costs, variable costs and results, as well as sustainability and the TBL (triple bottom line).

\section{Analysis of question 1}

The first proposed question, on the analysis of the restaurant's results, is of interest to several parties, including a) the owners, to manage the company; b) the Federal Revenue, to tax it; c) customers, to strengthen trust and loyalty; d) suppliers, to define their sales; e) banks, to decide on loans or take on the company as a client of the bank and f) employees, to analyze their jobs or participate in profit-sharing schemes.

This result is determined through the DRE. According to Assaf Neto (2020), this accounting statement presents, in summary form, the results of a company in a given period of time. In this way, it reflects the effect of the company's decisions on the performance of its activities, constituting one of the main instruments of analysis and financial planning.

Table 3 summarizes its main components: a) sales revenue or billing; b) COGS, which are the inputs used in the production of dishes; c) sales taxes; these two ("b" and " $\mathrm{c}$ ") are variable costs; d) gross profit or contribution margin, which is obtained by deducting from the billing amount, only variable costs; e) payroll; f) rent; g) other operating expenses such as water, energy, Internet, etc. ("e", "f", "g" are usually fixed costs); h) net income is the final result, which is obtained by deducting fixed costs from the gross income.

Variable costs are those that depend on the volume of production; they are closely linked to production and grow as the company's activity increases, while fixed costs are independent of the level of production (Bornia, 2010).

A table similar a DRE was used by Fonseca (2018) for the formation of the selling price (PV) practiced by restaurants, suggesting a model for the composition of expenses by the 
Income statement for the year (DRE)

a. Revenues

b. COGS

c. Sales taxes

d. Gross profit or Contribution margin

e. Payroll

f. Rent

g. Other operating expenses

h. Net profit

Source(s): The authors (2021)
Restaurante do Costinha

$\mathrm{R} \$ 2,100,000.00$

$\mathrm{R} \$(540,120.00)$

$\mathrm{R} \$(212,940.00)$

$R \$ 1,346,940.00$

$\mathrm{R} \$(470,400.00)$

$\mathrm{R} \$(180,000.00)$

$\mathrm{R} \$(350,000.00)$

$R \$ 346.540,00$
$100 \%$

$25.72 \%$

$10.14 \%$

$64.14 \%$

$22.40 \%$

$8.57 \%$

$16.67 \%$

$16.50 \%$

Texas Restaurant Association (TRA) Indexing Method, with the following indices on the PV: COGS of $35 \%$, operating expenses of $25 \%$ (Rent $7 \%$; Taxes $8 \%$; other expenses $10 \%$ ) and payroll of $30 \%$. If the restaurant manages to operate with these cost indices, its net profit will be $10 \%$ of the sale value, according to Table 4 . According to Table 5 (Braga, 2017), the classification parameter of restaurants in Brazil, Restaurante do Costinha is a luxury restaurant in terms of COGS, turnover and average ticket.

Analyzing the data from Restaurante do Costinha (Table 3) in light of the suggestions by Fonseca (2018), Table 4, the COGS $(25.72 \%)$ is well below the $35 \%$ suggested. This may be one of the reasons why the restaurant still is not too concerned about waste. Companies with a low COGS, such as Restaurante de Costinha, have a large profit margin, and waste can go unnoticed or ignored by the partners. It is important to highlight that the restaurant's COGS could be even lower if this waste were reduced.

One way to improve production processes and reduce this waste is to use a technical form when preparing the dishes. This form should be seen as a quality instrument in the production of meals (Akutsu, Botelho, Camargo, Sávio \& Araújo, 2005). Its use is an important factor for the management of restaurants, especially for working out the variable costs of preparations (Cardoso, 2011).

\begin{tabular}{lr}
\hline Revenue/Costs/Profit & Percentage \\
\hline Revenue (sales price) & $100 \%$ \\
COGS & $35 \%$ \\
Sales tax & $8 \%$ \\
Other operating expenses & $30 \%$ \\
Rent & $7 \%$ \\
Other operating expenses & $10 \%$ \\
Net profit & $10 \%$
\end{tabular}

Source(s): Adapted from Fonseca (2018, p. 129)

Table 4. Restaurant prices

\begin{tabular}{llll}
\hline Type & COGS & Turnover & Average ticket $(\mathrm{R} \$)$ \\
\hline Economic & $35 \%$ & 3 to 5 & Up to 15.00 \\
familiar & $33 \%$ & 2 to 4 & 15.00 to 35.00 \\
Moderate & $30 \%$ & 1.5 to 2.5 & 35.00 to 70.00 \\
Lux & $25 \%$ & Up to 1.5 & Over 70.00
\end{tabular}

Source(s): Braga (2017, p. 201)

Table 5.

Classification of restaurants in Brazil 
REGE

29,2

168

The sales tax rate $(10.14 \%)$ of Restaurante do Costinha, with annual revenues of $\mathrm{R} \$ 2.1 \mathrm{~m}$, is in accordance with the Simples Nacional Law for the commercial activity (Brasil, 2006) and with Decree No. 7212, of June 15, 2010 (Brazil, 2010), which considers a restaurant as a trading business.

Payroll is often the biggest fixed cost of companies like this. The restaurant has a payroll of $22.40 \%$ on sales. It represents a percentage well below $30 \%$, as suggested in the literature (Fonseca, 2018), which may signal to Costinha the need for a review of employee compensation, salary increases, which could represent a risk at times with low revenue, or a profit sharing policy.

After payroll, rent is the most significant cost for companies like Restaurante do Costinha, which has an index $(8.57 \%)$, just above the suggested value $(7 \%)$ for rent expenses. This can be explained by its privileged location, which attracts customers who are willing to pay a premium for the location.

Operating expenses include all other costs that have not yet been listed, such as water, energy, internet, marketing, insurance, etc. These costs are higher than those suggested in the literature, but each company has its fixed structure and that is why they differ. It is important to note that expenditure related to investments are not recorded in the DRE, for example, buying a machine. Its value is not consumed in the production process and therefore it is not configured as a cost, so it should not be considered in the DRE. Only the value of the depreciation of assets is a fixed cost (Megliorini, 2012) and must be deducted from the DRE.

Restaurante do Costinha's net profit of $16.50 \%$ is much higher than the $10 \%$ suggested by Fonseca (2018), which may be related to the low COGS and payroll values, which are usually the heaviest costs for this type of company.

Another interesting point for teachers in the disciplines of costs and financial management is that questions like this can be used to expand knowledge and use of tools such as electronic spreadsheets to calculate results (Table 3 ), elaboration of technical sheets for food management (Table 1) and internal rate of return (IRR) calculations (Table 6).

Regarding the IRR, this can be defined as the discount rate applied on the future values of a cash flow to zero this flow in the present moment (Puccini, 2011). It can be calculated by Excel with the formula entered in cell G2 (Table 6): = IRR(A2:F2), where A2 is the initial amount invested (negative sign) and B2 to F2 the net profits of the first five years, because the initial capital will all be depreciated over five years. The result is $199.17 \%$ per year. It is measured annually because the profit is calculated annually.

\section{Analysis of question 2}

The re-elaborated technical sheet (Table 7) with a 25\% reduction in side dishes, leaves $300 \mathrm{~g}$ of rice, vegetables, and mush, in response to question 2 . With the reduction in side dishes, as shown in Table 7 , the total weight drops to $2.065 \mathrm{~kg}$ and the COGS to $24.26 \%$. Table 8 is useful for the analysis of question 2.1.

Considering that COGS fell from $25.72 \%$ to $24.26 \%$ : a) the gross profit margin increased from $64.14 \%$ to $65.60 \%$; b) net income increased from $\mathrm{R} \$ 346,540.00$ to $\mathrm{R} \$ 377,200.00$, an increase of $\mathrm{R} \$ 30,660.00$ (Question 2.1).

In relation to waste (question 2.2), before this adaptation of the technical file, the amount of leftovers on tables was $200 \mathrm{~g}$ of food per person. There was a reduction of $150 \mathrm{~g}$ per person (300 $\mathrm{g}$ in Table 7, for two people). Thus, the $50 \mathrm{~g}$ per person in food left over at the table, plus the waste of $50 \mathrm{~g}$ per person for food that is produced but not served, makes a total of waste of $100 \mathrm{~g}$.

In Table 7, the new weight is $2.065 \mathrm{~kg}$ ( $1.033 \mathrm{~kg}$ per person), thus, the figure of $21.14 \%$ (250 $\mathrm{g}$ to $1.183 \mathrm{~kg}$ per person, Table 1 ) drops to $9.7 \%$ (100 $\mathrm{g}$ to $1.033 \mathrm{~kg}$ per people). This new waste rate is probably more acceptable to Mariana. For Maistro (2000), a 10\% waste rate is acceptable, but this does not mean that it is ideal from a perspective of sustainability. 


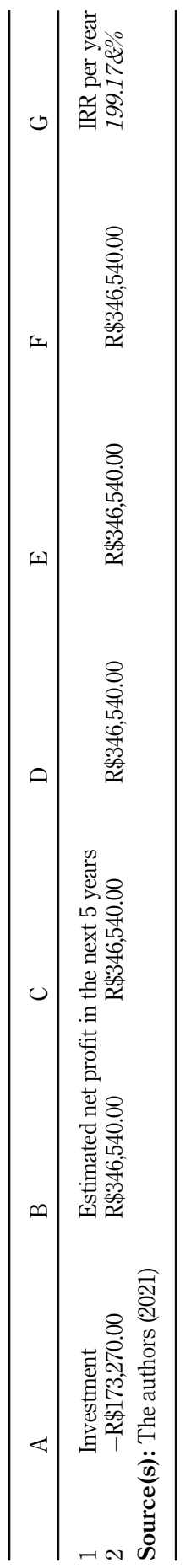

Restaurante do

Costinha

169

Table 6. Calculation of IRR 


\begin{tabular}{|c|c|c|c|c|c|}
\hline \multirow{3}{*}{$\begin{array}{l}\text { REGE } \\
29,2\end{array}$} & & \multirow{2}{*}{\multicolumn{2}{|c|}{$\begin{array}{c}\text { Sides } \\
\text { Rice, vegetables e mush (pirão) }\end{array}$}} & & \\
\hline & \multirow{2}{*}{$\begin{array}{l}\text { Product/Ingredients } \\
\text { Fish Mush } \\
\text { Ingredients }\end{array}$} & & & \multirow{2}{*}{ Input costs } & \multirow{2}{*}{$\begin{array}{l}\text { People Served } \\
2 \\
\text { Total }\end{array}$} \\
\hline & & $\mathrm{Kg}$ & Unit & & \\
\hline \multirow{4}{*}{170} & Rice & 0.300 & $\dddot{\mathrm{R}} \$ 2.90$ & & $\mathrm{R} \$ 0.87$ \\
\hline & Vegetables & 0.300 & $\mathrm{R} \$ 6.50$ & & $\mathrm{R} \$ 1.95$ \\
\hline & $\begin{array}{l}\text { Pirão } \\
\text { Total Kg }\end{array}$ & $\begin{array}{l}0.300 \\
2.065\end{array}$ & $\begin{array}{l}\mathrm{R} \$ 9.50 \\
\text { Total COGS }\end{array}$ & & $\begin{array}{l}\mathrm{R} \$ 2.85 \\
R \$ 31.54\end{array}$ \\
\hline & Price & $R \$ 130,00$ & Profit\% & & R\$98.46 \\
\hline \multirow{3}{*}{$\begin{array}{l}\text { Table } 7 . \\
\text { Datasheet with } \\
\text { reductions }\end{array}$} & COGS\% & $24.26 \%$ & Profit\% & & $75.74 \%$ \\
\hline & Cost per Kg & $R \$ 15.28$ & Per Client & & $R \$ 65.00$ \\
\hline & Source(s): The Authors (2021) & & & & \\
\hline
\end{tabular}

Income statement for the year (DRE)

\begin{tabular}{lcr}
\hline a. Revenues & $2,100,000.00$ & $100 \%$ \\
b. COGS & $(509,460.00)$ & $24.26 \%$ \\
c. Sales taxes & $(212,940.00)$ & $10.14 \%$ \\
d. Gross profit or spread & $1.377 .600,00$ & $65.60 \%$ \\
e. Payroll & $(470,400.00)$ & $22.40 \%$ \\
f. Rent & $(180,000.00)$ & $8.57 \%$ \\
g. Operating expenses & $(350,000.00)$ & $16.67 \%$ \\
h. Net profit & $377,200.00$ & $17.96 \%$ \\
Source(s): The authors (2021) & &
\end{tabular}

\section{Analysis of question 3}

Restaurante do Costinha carries out several sustainable practices, such as the use of organic food from local family producers, and integrating with the community, in addition to its seafood specialty. The improvements that can be implemented in relation to sustainability relate to the food production process, aimed at reducing leftovers and, consequently, waste, as well as reforms in the structure of the property for the installation of rainwater and rainwater collection systems and solar energy.

Such practices bring economic, environmental and social advantages. In addition to bringing benefits to the region, they generate savings, as their adoption reduces costs of water, energy and raw materials, etc. Furthermore, they can attract more customers concerned about environmental issues, and improve the health and quality of life of employees, resulting in greater productivity.

The issue involves the concept of sustainability and sustainable organizations, which is very important for understanding how practices occur in organizations. The World Commission on Environment and Development (WCED) (1987) defines sustainability as "Development that meets the needs of the present without compromising the ability of future generations to meet their needs" (p. 8). However, this definition is complex to apply in medium and small organizations. It does not explain how they should identify present versus future needs, or the use technologies and resources to meet those needs, or how to effectively balance organizational responsibilities across multiple stakeholders (Gimenez, Sierra \& Rodon, 2012).

The WCED definition is widely recognized as it integrates social, environmental and economic issues. The easiest way to operationalize sustainable practices is through the TBL, 
a concept developed by Elkington (1994), which considers and balances economic, environmental and social issues from an organizational point of view. According to Barbieri, Vasconcelos, Andreassi and Vasconcelos (2010), a sustainable organization is one that simultaneously seeks to be efficient in economic terms, respect the support capacity of the environment, and act as an instrument of social justice, promoting social inclusion, protection of minorities and vulnerable groups, gender balance, etc.

Authors such as Gimenez et al. (2012) argue that economic sustainability is generally wellunderstood. At the level of organizations, it was operationalized as a reduction in production or operating costs. However, it is not always easy to define environmental and social sustainability. For these same authors, environmental sustainability refers to the use of energy and other resources that companies use in their operations. The most commonly applied practices are the reduction of pollution, waste, emission of toxic gases, reduction in the consumption of hazardous and harmful materials, the frequency of environmental accidents, energy efficiency, etc.

Social sustainability shifts the focus to the internal (employees) and external community (Pullman, Maloni \& Carter, 2009). It involves organizations that provide equitable opportunities, encourage diversity, promote connection within and outside the community, ensure quality of life, and provide democratic processes and responsible governance structures (Elkington, 1994).

The TBL concept suggests that restaurants not only need to engage in socially and environmentally responsible behavior, but also that positive financial gains can be made in the process. In this teaching case, we analyzed the impact of social and environmental activities at Restaurante do Costinha, quantifying its impact as more than $\mathrm{R} \$ 1 \mathrm{~m}$, without quantifying the actions involved to attract more customers, as shown in Table 9, which describes and quantifies the impacts social, environmental and economic aspects that Restaurante do Costinha serves by adopting these practices.

\section{Analysis of question 4}

Different studies on sustainability are being developed around the world, mainly regarding the SDGs. The SDGs are part of the 2030 agenda signed by representatives of the signatory countries of the United Nations (UN), in September 2015, during the Summit on Sustainable Development (United Nations, B, 2015). Consisting of 17 goals (Figure 1) and 169 goals to be achieved by 2030, the SDGs are considered a major milestone for global development, with a partnership between civil society organizations, businesses and government, which seek specific actions for poverty, prosperity, well-being, the environment and climate change.

The intention of question 4 is to enable students to learn about and be able to assess the restaurant's actions in relation to the SDGs. They can still envision other goals, as long as they argue the answer well.

For example, based on Figure 1, it is possible to relate the sustainable practices of Restaurante do Costinha with the following SDGs: (1) one, eight and ten, as it generates work and income for suppliers in the local community; (2) three, due to healthy eating and concern for the well-being of customers and workers; (3) five, because Costinha and Mariana have the same decision-making power over the restaurant's issues and thus demonstrate respect for gender equality in their personal and professional relationships; (4) fourteen, due to their specialty in seafood; (5) eleven, twelve, thirteen and fifteen, which are the highlights of this case for teaching focused on the issue of food waste, in addition to Mariana's attention to the collection of rainwater and solar energy.

\section{Additional questions}

As this is an "armchair" case, we can disregard the item "outcome" and move on to some additional questions that can be used in its application. 
REGE

29,2

Questions 3.1 e 3.2

Dimensions Description of impacts Sustainable practices Impacts/Quantification

Social Social concern for social impacts and innovations in human communities inside and outside

the organization (unemployment, social exclusion, poverty, organizational diversity, etc.)

Environmental Concern about environmental impacts from the use of natural resources and pollutant emissions

Economic Concern for economic efficiency, without which they cannot be perpetuated. For companies, this dimension means profit and

Table 9.

Social, environmental and economic impactsRestaurante do Costinha

Total

market in which they operate
Hire staff from the community where the restaurant is located Suppliers of small family nuclei products

Decrease in waste

Pesticide-free organic products

Restaurant becomes recognized for its sustainable activities Rainwater harvesting and solar energy
Job generator, 14 employees with a direct impact on their families: $R \$ 470,400.00 /$ year Income for family producers. COGS comes from these producers: $R \$ 509,460.00 /$ year

Reduction of up to $7,000 \mathrm{~kg}$ of waste per year. Cost of $\mathrm{kg}$ R\$14.14: R\$98,980.00/year

Healthy and organic food offer

Niche customers looking for organic products

Reduction of annual expenditure on water and energy: $R \$ 36,000.00 /$ year $R \$ 1,114,840.00$

Source(s): The authors (2021)

Figure 1.

Sustainable development goals
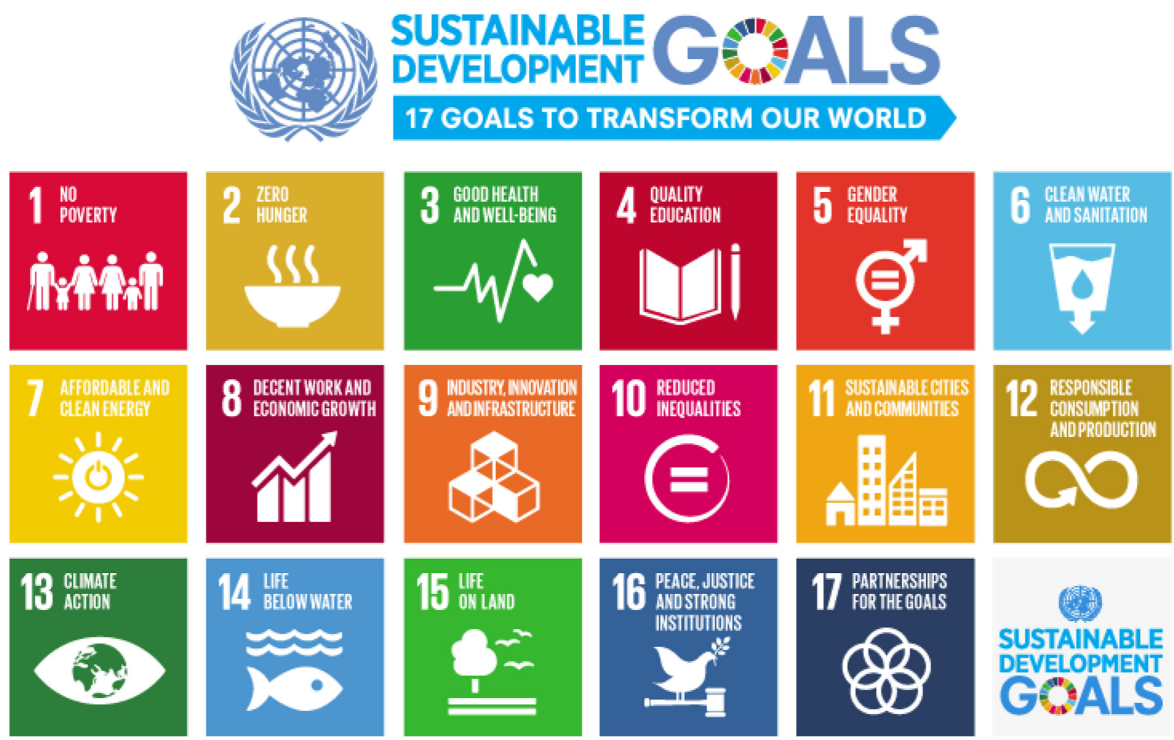

SUSTAINABLE DEVELOPMENT GOALS

Source(s): United Nations, B. (2015) 
Courses on costs and financial management can work with the students in the elaboration of electronic spreadsheets, in the program of Gastronomy with Table 1, technical sheet, even being able to change the recipes. In the Business Administration course, teachers can work with spreadsheets to solve proposed question 1 , with other simulated values.

The case questions can also be used in applied research in micro and small businesses related to students. The DRE and the preparation technical sheet (proposed in questions 1 and 2) can serve as an initial basis for consultancy in the field of engineering and menu planning or financial management.

Another issue may be a survey to be carried out by students on the social, environmental and economic aspects that contributed to the success of Restaurante do Costinha in the face of its competitors. Another may be the tools used by Mariana to set up her strategic planning.

\section{References}

Akutsu, R.D.C., Botelho, R.A., Camargo, E.B., Sávio, K.E.O., \& Araújo, W.C. (2005). A ficha técnica de preparação como instrumento de qualidade na produção de refeições. Revista Nutrição, 18(2), 277-279.

Alberton, A., \& Silva, A.B.D. (2018). Como Escrever um Bom Caso para Ensino? Reflexões sobre o Método. Revista de Administração Contemporânea, 22(5), 745-761, doi: 10.1590/19827849rac2018180212.

Assaf Neto, A. (2020). Estruturas e análise de Balanços - um enfoque econômico-financeiro, $12^{\mathrm{a}}$. São Paulo: Atlas.

Barbieri, J.C., Vasconcelos, I.F.G.D., Andreassi, T., \& Vasconcelos, F.C.D. (2010). Inovação e sustentabilidade: Novos modelos e proposições. Revista de Administração de Empresas, 50(2), $146-154$.

Bornia, C. (2010). Análise gerencial de custos : Aplicação em empresas modernas, $3^{\mathrm{a}}$. São Paulo: Atlas.

Braga, R.M.M. (2017). Gestão da gastronomia : Custos, formação de preços, gerenciamento e planejamento do lucro, 5 a . São Paulo: Senac.

Brasil (2006). Lei Complementar No 123, de 14 de dezembro de 2006. available at: http://www.planalto. gov.br/ccivil_03/leis/lcp/lcp123.htm.

Brasil (2010). Decreto no 7212, de 15 de junho de 2010, available at: http://www.planalto.gov.br/ccivil_ 03/_ato2007-2010/2010/decreto/d7212.htm.

Campos, R.D., \& Almeida, V.M.C.de. (2014). Método do caso: 'Não Sei, Não ...' Enfrentando as barreiras À implantação do método. Administração: Ensino e Pesquisa, 15(1), 43-72. doi: 10. 13058/raep.2014.v15n1.42.

Cardoso, J.de F. (2011). Custos e preço de Venda: Um estudo em restaurantes à la carte. Revista Hospitalidade, 2, 103-120, available at: https:/www.revhosp.org/hospitalidade/article/ view/395.

Elkington, J. (1994). Towardsthesustainablecorporation:win-win-winbusiness strategies forsustainabledevelopment. CaliforniaManagementReview, 36(2), 90-100.

FAO (2017). FAO: 30\% de toda a comida produzida no mundo vai parar no lixo, (13), 9-11, available at: https://nacoesunidas.org/fao-30-de-toda-a-comida-produzida-no-mundo-vai-parar-no-lixo/.

Faria, M., \& Figueiredo, K.F. (2013). Casos de ensino no brasil: Análise bibliométrica e orientações para autores. Revista de Administração Contemporânea, 17(2), 176-197. doi: 10.1590/s141565552013000200004 .

Fonseca, M.T. (2018). Tecnologia gerenciais de restaurantes. São Paulo: Senac.

Gimenez, C., Sierra, V., \& Rodon, J. (2012). Sustainable operations: Their impact on the triple bottom line. International Journal of Production Economics, 140(1), 149-159. 
REGE

29,2
Ikeda, A.A., \& Campomar, M.C. (2005). A tipologia do método do caso em administração: Usos e aplicações. Organizações \& Sociedade, 12(35), 141-159, doi: 10.1590/\$1984-92302005000300009.

Linassi, R., Alberton, A., \& Marinho, S.V. (2016). Menu engineering and activity-based costing: An improved method of menu planning. International Journal of Contemporary Hospitality Management, 28(7), 1417-1440. doi: 10.1108/IJCHM-09-2014.

Maistro, L. (2000). Estudo do índice de Resto ingestão em Serviços de Alimentação. Nutrição Em Pauta, Nov/Dez. available at: https://www.nutricaoempauta.com.br/lista_artigo.php?cod=123.

Megliorini, E. (2012). Custos: Análise e gestão, $3^{\text {a }}$. São Paulo: Pearson Prentice Hall.

Puccini, A.D.L. (2011). Matemática financeira objetiva e aplicada. 6 a edição, 1. São Paulo, SP: Saraiva.

Pullman, M.E., Maloni, M.J., \& Carter, C.R. (2009). Food for thought: Social versus environmental sustainability practices and performance outcomes. Journal of Supply Chain Management, 45(4), $38-54$.

United Nations, B (2015). Transformando nosso mundo: A agenda 2030 para o desenvolvimento sustentável, available at: https://nacoesunidas.org/pos2015/agenda2030/.

WCED, S.W.S. (1987). World commission on environment and development. Our Common Future, 17, $1-91$.

\section{Further reading}

Fombrun, C.J. (2005). The leadership challenge: Building resilient corporate reputations. Handbook on Responsible Leadership and Governance in Global Business, 54, 68.

\section{Corresponding author}

Pedro José Raymundo can be contacted at: pjraymundo30@gmail.com

Associate Editor: Rodrigo Morais-da-Silva

For instructions on how to order reprints of this article, please visit our website:

www.emeraldgrouppublishing.com/licensing/reprints.htm

Or contact us for further details: permissions@emeraldinsight.com 